\title{
Pengaruh Pemberian Gaji terhadap Motivasi Kerja dan Profesionalisme Guru Honor
}

\author{
Stefania Seto, Juwita Merdja \\ Program Studi Pendidikan Matematika Fakultas Keguruan dan Ilmu Pendidikan \\ Universitas Flores
}

Email: Stefania@gmail.co.id

\begin{abstract}
ABSTRAK
Penelitian ini bertujuan untuk mengetahui pengaruh langsung pemberian gaji terhadap motivasi dan efektifitas pembelajaran guru dalam proses pembelajaran. Pemberian gaji merupakan bentuk terima kasih atas kerja keras para guru dalam hal ini staf honorer yang telah mendedikasikan diri sebagai guru. Dengan pemberian gaji itu akan memotivasi guru dalam proses belajar mengajar di kelas. Populasi dalam penelitian ini adalah guru di Kabupaten Ende yang termasuk dalam kategori guru sukarela dengan gaji yang diperoleh berdasarkan komite dan dari bantuan operasional sekolah atau yang biasa disebut dengan dana BOS. Metode penelitian adalah penelitian survei dengan pendekatan analisis jalur. Pengumpulan data dilakukan dengan menggunakan kuesioner, yang telah diuji. Hasil penelitian menunjukkan bahwa ada pengaruh langsung positif dan signifikan terhadap pemberian gaji, dan motivasi kerja terhadap profesionalisme guru. Untuk alasan ini, diperlukan kebijakan untuk meningkatkan profesionalisme guru, perlu untuk meningkatkan penyediaan gaji dan motivasi kerja.
\end{abstract}

Kata Kunci: Gaji; Motivasi; Guru: Professionalisme

\begin{abstract}
This study aims to determine the direct effect of salary giving on the motivation and effectiveness of teacher learning in the learning process. The provision of salary is a form of gratitude for the hard work of the teachers in this case honorary staff who have dedicated themselves as teachers. With the provision of salary it will motivate the teacher in the teaching and learning process in the classroom. The population in this study were teachers in Ende district who were included in the voluntary teacher category with salaries obtained based on committees and from school operational assistance or commonly referred to as BOS funds. The research method is a survey research with path analysis approach. Data collection was carried out using a questionnaire, which has been tested. The results of the study showed that there was a positive and significant direct effect on salary giving, and work motivation on teacher professionalism. For this reason, policies are needed to improve teacher professionalism, it is necessary to increase the provision of salaries and work motivation.
\end{abstract}

Keywords: Salary; Motivation; Teacher; Professionalism

(C) 2020 Stefania Seto, Juwita Merdja Under The License CC-BY SA 4.0

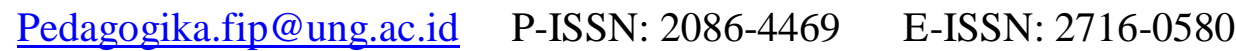




\section{PEDAGOGIKA}

Volume 11 (Nomor 1) 2020

Hal. 42-48

\section{PENDAHULUAN}

Proses pembelajaran yang terjadi dalam dunia pendidikan tidak terlepas dari peran guru Honorer. Guru honorer juga menjalankan kewajiban yang sama dengan para guru PNS dalam pembelajaran di kelas. Terkadang banyak orang yang menyepelekan kehadiran guru honorer di sekolah-sekolah. Padahal dalam kenyataannya guru honorer sangat membantu dalam proses pembelajaran di kelas. Gaji yang diperoleh guru honorer merupakan hasil dari komite sekolah dan juga dari bantuan operasional sekolah. Para guru honorer juga menjalankan kewajiban yang sama dalam penyusunan RPP, Silabus dan program kerja yang terjadi di sekolah.

Gaji merupakan salah satu faktor yang penting dalam meningkatkan motivasi kerja sebab gaji merupakan sarana untuk memenuhi berbagai kebutuhan para karyawan. Tulus, (2011:140) "Gaji adalah sejumlah uang yang diterima oleh tenaga tenaga majeria dan tata usaha atas sumbangan jasanya, yang menerima uang dengan jumlah yang tetap berdasakan tarif bulanan”. Menurut Moeheriono (2012:87) didalam bukunya menjelaskan bahwa: "Besarnya gaji pokok ataupun tunjangan yang diberikan kepada karyawan, pada saatsaat tertentu dievaluasi.
Menurut Soemarso (2009: 307), gaji didefenisikan sebagai "Imbalan kepada yang diberikan atas tugas-tugas administrasi dan pimpinan yang biasa jumlahnya tetap secara bulanan". Berdasarkan beberapa pengertian diatas maka dapat disimpulkan bahwa pemberian gaji merupakan bentuk penghargaan yang diberikan untuk meningkatkan motivasi kerja.

Dalam pengertian umum, motivasi dikatakan sebagai kebutuhan yang mendorong perbuatan kearah suatu tujuan tertentu. Motivasi adalah dorongan atau keinginan individu untuk melakukan kegiatan tertentu dalam mencapai tujuan. Robbins (2007:208) menyebutkan bahwa motivasi sebagai suatu proses yang menghasilkan intensitas, arah dan ketekunan individual dalam usaha untuk mencapai satu tujuan. Colquitt, Lepine, and Wesson (2009) menjelaskan motivasi adalah suatu kumpulan kekuatan energik yang mengkoordinasi di dalam dan di luar diri seorang pekerja, yang mendorong usaha kerja dalam menentukan arah perilaku, tingkat usaha, intensitas dan kegigihan. Luthans (2005:141) mengatakan motivasi adalah suatu proses di dalam diri seseorang karena memiliki kebutuhan psikologis dan fisiologis sehingga mengerakkan perilaku atau dorongan untuk 


\section{PEDAGOGIKA}

Volume 11 (Nomor 1) 2020

Hal. 42-48

mencapai suatu tujuan. Dari beberapa pengertian diatas maka motivasi merupakan dorongan yang terjadi dalam diri seseorang secara sadar untuk melakukan sesuatu. Motivasi kerja adalah sikap seseorang terhadap pekerjaannya yang mengarah pada kepuasan kerja (Herzberg dalam Robbins, 1996). Motivasi kerja diartikan sebagai keadaan yang terjadi pada diri individu itu sendiri yang mendorong keinginan tertentu guna mencapai suatu tujuan tertentu. Dari beberapa pengertian di atas dapat disimpulkan bahwa motivasi kerja adalah sikap sadar dari seorang individu untuk melakukan pekerjaannya untuk suatu tujuan tertentu.

Profesionalisme berasal dari kata profesi yang mengandung arti jabatan atau pekerjaan seseorang. Orang yang profesional adalah orang yang mampu menjalankan tugasnya dengan baik dan bertanggung jawab. Kriteria profesionalisme guru meliputi kemampuan: menguasai bahan pengajaran, pengelolaan kelas, dan mengenal dengan baik keadaan kelas maupun sekolah termasuk siswa-siswi dan rekan guru. Profesionalisme menuntut keseriusan dan kompetensi yang memadai, sehingga seorang dianggap layak dalam menjalankan tugas. Profesionalisme guru sering dikaitkan dengan tiga faktor yang cukup penting, yaitu kompetensi guru, sertifikasi guru dan tunjangan profesi guru. Jadi guru yang professional adalah guru yang menyadari bahwa dirinya terpanggil untuk mendampingi perserta didik dalam pembelajaran. Bagi guru yang professional, dia harus memiliki criteria-kriteria tertentu yang positif. Gilbert H. Hunt menyatakan bahwa guru yang baik itu harus memenuhi tujuh kriteria: (1) sifat positif dalam membimbing peserta didik, (2) pengetahuan yang memadai dalam mata pelajaran yang dibina, (3) mampu menyampaiakn materi secara lengkap, (4) mampu menguasai metodologi pembelajaran, (5) mampu memberikan harapan riil terhadap peserta didik, (6) mampu mereaksi kebutuhan peserta didik, (7) mampu menguasai manajemen kelas. (I Nengah Sudja: 2013. $223-224)$.

Menjadi guru yang professional dan mempunyai kinerja yang baik harus didukung dengan jaminan kehidupan dan fasilitas yang baik juga. Sebagaimana dinyatakan Tilaar (1999:104) bahwa peningkatan kualitas pendidikan tergantung banyak hal, terutama mutu gurunya. Ini menunjukkan bahwa tugas guru tidaklah 


\section{PEDAGOGIKA}

Volume 11 (Nomor 1) 2020

Hal. 42-48

mudah. Guru harus memiliki kemampuan dan ketrampilan yang bersifat professional.

Menurut Undang - undang Nomor 20

Tahun 2003 tentang Sistem Pendidikan

Nasional pasal 1 ayat 5, menjelaskan bahwa tenaga kependidikan adalah anggota masyarakat yang mengabdikan diri dan diangkat untuk menunjang penyelenggaraan pendidikan. Proses belajar mengajar di dalam kelas merupakan inti dari proses pendidikan secara keseluruhan dan guru adalah pemegang pemeran utama, karena guru merupakan pelaksana pendidikan yang memiliki peran penting dalam keberhasilan pendidikan. Produktivitas kerja guru SMP di Kabupaten Ende masih perlu ditingkatkan. Pemberian gaji merupakan salah satu jenis motivasi ekstrinsik karena bersumber dari kondisi di luar individu. Insentif menurut Rivai (2004:53), diartikan sebagai bentuk pembayaran yang dikaitkan dengan kinerja dan gain sharing, sebagai pembagian keuntungan bagi karyawan akibat peningkatan produktivitas atau penghematan biaya. Sistem ini merupakan bentuk lain dari kompensasi langsung di luar gaji dan upah yang merupakan kompensasi tetap, yang disebut sistem kompensasi berdasarkan kinerja (pay for performance plan).
Fenomena yang terjadi di lapangan berbeda dengan apa yang terjadi.. Hasil pengamatan penulis di lapangan menunjukkan bahwa kesejahteraan guru di daerah ini masih memprihatinkan. Masih ada guru yang mencari tambahan pendapatan, di luar jam kerja; gaji dan insentif (finansial) yang diterima guru masih dirasakan kurang mencukupi kebutuhan guru dan keluarga secara layak; masih ada kasus guru yang meninggalkan tugas mengajar, karena mencari tambahan pendapatan; serta beberapa kebijakan pemerintah menyebabkan harga barang kebutuhan hidup menjadi tinggi, sehingga gaji dan insentif yang diterima menjadi berkurang untuk menutupi kebutuhan sehari-hari guru dan keluarga.

Pemberian gaji yang cukup akan sangat memotivasi guru dalam pengajaran dan selalu besikap profesionalisme. Tetapi kenyataan yang terjadi di Kabupaten Ende, pemberian gaji tidak sesuai dengan proporsi kerja dari para guru honor itu sendiri. ini yang menyebabkan motivasi dan profesionalisme guru menjadi sangat rendah dikarenakan pemberian gaji bagi para guru honor terbilang rendah. Oleh karena itu peneliti tertarik untuk melakukan penelitian dengan judul "Pengaruh Pemberian Gaji

\section{$\underline{\text { Pedagogika.fip@ung.ac.id } \quad P-I S S N: ~ 2086-4469 ~ E-I S S N: ~ 2716-0580 ~}$}


PEDAGOGIKA

Volume 11 (Nomor 1) 2020

Hal. 42-48

Terhadap Motivasi Kerja dan

Profesionalisme Guru Honor Di Kabupaten

Ende"

\section{METODE PENELITIAN}

Jenis penelitian yang digunakan adalah penelitian kuantitatif yang menggunakan analisis regresi berganda, Dalam penelitian terdapat tiga variabel penelitian yaitu pemberian gaji, motivasi kerja, dan profesionalisme guru.

Populasi dalam penelitian ini adalah guru SMP di Kabupaten Ende. Adapun penarikan sampel berdasarkan metode purposive sampling dengan cara memilih sampel berupa guru yang berstatus Guru Honorer yang berjumlah 75 orang

Analisis data menggunakan analisis regresi. Pertama, menentukan model penelitian dan merumuskan persamaan strukturalnya sesuai dengan hipotesis penelitian yang diajukan. Kemudian melakukan estimasi parameter model dan dilanjutkan dengan melakukan pengujian model. Pengujian model dilakukan dengan tiga tahap, yaitu evaluasi asumsi statistik, uji koefisien determinasi, uji keseluruhan dengan menggunakan uji $F$, dan uji individual dengan menggunakan uji $t$. seluruh pengolahan data kuantitatif menggunakan program komputer SPSS 21.

\section{HASIL PENELITIAN DAN PEMBAHASAN}

Hasil penelitian yang diperoleh didasarkan pada tujuan penelitian yang telah ditetapkan. Dalam penelitian ini menunjukkan motivasi kerja mengajar guru SMP di Kabupaten Ende, berada pada kategori sedang. Hal ini terlihat dari skor rata-rata jawaban responden untuk variabel motivasi kerja mengajar guru sebesar 2.15. Artinya, sejauh ini motivasi kerja guru dalam melakukan proses belajar mengajar masih kurang efektif.

Secara keseluruhan pemberian gaji honorer terhadap motivasi kerja guru sangat berpengaruh dan tidak berkontribusi secara signifikan terhadap profesionalisme mengajar guru sebesar $73 \%$. Sisanya yaitu sebesar $27 \%$ merupakan pengaruh yang datang dari faktorfaktor lain. Misalnya: kemampuan guru, kepemimpinan, iklim organisasi sekolah, etos kerja, budaya organisasi, dan lain-lain.

Variabel pemberian gaji bagi honorer Pada SMP di Kabupaten Ende, berada pada kategori cukup. Hal ini terlihat dari skor ratarata jawaban responden untuk variabel pemberian gaji sebesar 1.23. Artinya, pemberian gaji pada guru honorer tidak dikelola dengan baik oleh kepala sekolah, maupun pemerintah daerah. Adapun 


\section{PEDAGOGIKA}

Volume 11 (Nomor 1) 2020

Hal. 42-48

berdasarkan hasil perhitungan SPSS, variabel pemberian gaji $(\mathrm{Xi})$ terhadap motivasi kerja mengajar guru pada SMP di Kabupaten Ende sebesar 0,225. Artinya tinggi rendahnya motivasi kerja mengajar guru pada SMP di Kabupaten Ende (Y) dipengaruhi oleh pemberian gaji (Xi) sebesar $r^{*}$ x $100 \%$ atau $0,325^{*} \times 100 \%=10.56 \%$.

Variabel profesionalisme guru honorer pada SMP di Kabupaten Ende, berada pada kategori sedang Hal ini terlihat dari skor rata- rata jawaban responden untuk variabel profesionalisme guru sebesar 2.30. Artinya, kurangnya pemenuhan kebutuhan yang berasal dari pemberian gaji bagi para guru honorer sangat berpengaruh terhadap profesionalisme guru baik dalam proses persiapan pembelajaran maupun dalam prses pengajaran di dalam kelas.

Adapun berdasarkan hasil perhitungan SPSS, variabel profesionalisme guru $\left(\mathrm{X}_{2}\right)$ terhadap motivasi kerja mengajar guru pada SMP di Kabupaten Ende (Y) sebesar 0,330. Artinya tinggi rendahnya motivasi kerja mengajar guru pada SMP di Kabupaten Ende (Y) dipengaruhi profesionalisme guru $\left(\mathrm{X}_{2}\right)$ sebesar $r^{2} \times 100 \%$ atau $0,330^{2} \mathrm{x}$ $100 \%=10.89 \%$.

Sesuai penelitian Djati (1999) bahwa variabel-variabel motivasi menunjukkan pengaruh yang bermakna terhadap produktivitas tenaga keija. Doloi (2007) dalam penelitiannya yang berjudul Twinning Motivation, Productivity and Management Strategy in Construction Projects menunjukkan bahwa motivasi sangat berkaitan dengan produktivitas kerja.

\section{KESIMPULAN}

Berdasarkan hasil analisis data dan pembahasan, peneliti dapat menarik kesimpulan sebagai berikut: Variabel pemberian gaji bagi honorer Pada SMP di Kabupaten Ende, berada pada kategori cukup. Hal ini terlihat dari skor rata-rata jawaban responden untuk variabel pemberian gaji sebesar 1.23. Artinya, pemberian gaji pada guru honorer tidak dikelola dengan baik oleh kepala sekolah, maupun pemerintah daerah. Adapun berdasarkan hasil perhitungan SPSS, variabel pemberian gaji (X1) terhadap motivasi kerja mengajar guru pada SMP di Kabupaten Ende sebesar 0,225. Artinya tinggi rendahnya motivasi kerja mengajar guru pada SMP di Kabupaten Ende (Y) dipengaruhi oleh pemberian gaji (Xi) sebesar $r^{*} \times 100 \%$ atau $0,325^{*} \times 100 \%=$ $10.56 \%$. Variabel profesionalisme guru honorer pada SMP di Kabupaten Ende, berada pada kategori sedang Hal ini terlihat 
PEDAGOGIKA

Volume 11 (Nomor 1) 2020

Hal. 42-48

dari skor rata- rata jawaban responden untuk variabel profesionalisme guru sebesar 2.30. Artinya, kurangnya pemenuhan kebutuhan yang berasal dari pemberian gaji bagi para guru honorer sangat berpengaruh terhadap profesionalisme guru baik dalam proses persiapan pembelajaran maupun dalam proses pengajaran di dalam kelas. Adapun berdasarkan hasil perhitungan SPSS, variabel profesionalisme guru $\left(\mathrm{X}_{2}\right)$ terhadap motivasi kerja mengajar guru pada SMP di Kabupaten Ende (Y) sebesar 0,330. Artinya tinggi rendahnya motivasi kerja mengajar guru pada SMP di Kabupaten Ende (Y) dipengaruhi profesionalisme guru $\left(\mathrm{X}_{2}\right)$ sebesar $\mathrm{r}^{2} \mathrm{x} 100 \%$ atau $0,330^{2}$ x $100 \%=10.89 \%$. Secara keseluruhan pemberian gaji honorer terhadap motivasi kerja guru sangat berpengaruh dan tidak berkontribusi secara signifikan terhadap profesionalisme mengajar guru sebesar $73 \%$. Sisanya yaitu sebesar $27 \%$ merupakan pengaruh yang datang dari faktor-faktor lain.

\section{REFERENSI}

Colquitt, Lepine, Wesson. 2009. Organizational Behavior Improving Performance and Commitment in The Workplsce, International Edition, McGraw-Hill, New York
Doloi, Hemanta. (2007). Twinning Motivation, Productivity and Management Strategy in Constmction Projects. Engineering Management Journal.

Luthans, F. 2005. Organizational Behavior. Seventh Edition. McGraw-Hill, New York

Moeheriono. 2012. "Pengukuran Kinerja Berbasis Kompetensi”. Jakarta: Raja Grafindo Persada.

Rivai, Veithzal. (2004). Manajemen Sumber Daya Manusia untuk Perusahaan. Jakarta: Rajagrafindo Persada.

Robbins, Stephen P. and MaryCoulter.2007. Management. New Jersey: Pearson Education, Inc.

Robbins, Stephen P. 2006. Perilaku Organisasi.terjemahan Benyamin Molan. Indonesil

S R, Soemarso. 2009. Akutansi Suatu Pengantar. Buku 1. Jakarta: Salemba Empat.

Tilaar, H.A.R. Beberapa Agenda Rreformasi Pendidikan Nasional, Dalam Perpektif Abad 21, Magelang: Putera Indonesia, 1999.

Tulus TH Tambunan. (2011). Industrialisasi di Negara Sedang Berkembang Kasus Indonesia. Jakarta: Ghalia Indonesia. 